\title{
UPAYA MENINGKATKAN HASIL BELAJAR IPS MENGGUNAKAN METODE PETA KONSEP BAGI SISWA KELAS III SD NEGERI 1 SUBAGAN
}

\section{NYOMAN TAMBUN ARIANTA}

SD Negeri 1 Subagan

e-mail: inyomantambunarianta8@gmail.com

\begin{abstract}
ABSTRAK
IPS merupakan bagian dari ilmu sosial, keberadaan IPS dalam struktur program pembelajaran di SD sangat penting untuk diajarkan karena IPS memberikan pengetahuan, pembentukan nilai dan sikap serta keterampilan kepada siswa secara langsung berinteraksi dengan lingkungan yang ada di sekitarnya. Selama ini pembelajaran IPS di SD Negeri 1 Subagan yang dilaksanakan cenderung ke arah pembahasan teori yang bersifat khusus (tematik teoritik) dan berdasarkan materi yang ada di dalam buku (text book oriented) sehingga terkesan bahwa bidang ini terdiri dari materi hafalan saja. Dari hasil pembelajaran IPS terdapat 8 siswa $(25,53 \%)$ dari 34 siswa yang mencapai KKM, sedangkan 26 siswa (76,47\%) belum mencapai KKM dengan nilai rata-rata yang diperoleh 60,82. Guna mengatasi permasalahan tersebut maka peneliti akan mencoba menggunakan metode yang dapat diterima dan mudah dipahami siswa kelas III SD Negeri 1 Subagan. Metode yang digunakan oleh peneliti ialah metode peta konsep. Dengan melihat latar belakang tersebut, maka rumusan masalah dalam penelitian ini adalah: Apakah metode peta konsep dapat meningkatkan hasil belajar IPS pada siswa kelas III SD Negeri 1 Subagan Tahun Pelajaran 2017/2018?. Tujuan penelitian adalah untuk meningkatkan hasil belajar IPS dengan menggunaan metode peta konsep pada siswa kelas III SD Negeri 1 Subagan Tahun Pelajaran 2017/2018. Penggunaan Metode Peta Konsep Dalam Upaya Meningkatkan Hasil Belajar IPS Bagi Siswa Kelas III SD Negeri 1 Subagan Tahun Pelajaran 2017/2018 mengalami peningkatan, yaitu sebelum diterapkannya metode peta konsep pada pembelajaran Ilmu Pengetahuan Sosial, diperoleh sebanyak 8 siswa atau 25,53\% tuntas dan 26 siswa atau 76,47\% belum tuntas. Namun setelah dilakukan tindakan dengan menerapkan metode peta konsep dalam pembelajaran Ilmu Pengetahuan Sosial yang efektif dapat memperbaiki pola pembelajaran dan dapat meningkatkan hasil belajar siswa yang ditandai dengan ketuntasan hasil belajar disetiap siklusnya. Keberhasilan ini disebabkan dengan penerapan metode peta konsep dengan menanamkan konsep-konsep pokok sehingga aktivitas siswa menjadi aktif dan senang mengikuti pembelajaran. Berarti siswa ceenderung positif dalam mengikuti proses belajar mengajar yang diberikan guru maupun dalam melakukan diskusi serta tanya jawab di dalam kelas. Hal tersebut dapat dilihat dari hasil belajar pada siklus I dan II diperoleh data bahwa hasil belajar siswa meningkat. Hasil tes siklus I diperoleh sebanyak 20 siswa atau 58,52\% tuntas dan 14 siswa atau 41,13\% belum tuntas. Kemudian pada hasil tes siklus II menunjukkan 31 siswa atau 91,17\% tuntas dan 3 siswa atau $8,83 \%$ belum tuntas. Dengan adanya peningkatan yang terjadi pada siswa yang telah mencapai 91,17\% siswa telah tuntas dan melebihi $75 \%$ indikator keberhasilan maka dinyatakan bahwa perbaikan pembelajaran ini telah berhasil
\end{abstract}

Kata Kunci: Metode Pembelajaran Peta Konsep, hasil belajar, IPS

\section{PENDAHULUAN}

Upaya pembaharuan pendidikan untuk meningkatkan kualitas pendidikan dilakukan secara inovatif. Hal tersebut lebih terfokus lagi setelah diamanatkan oleh pemerintah bahwa tujuan pendidikan nasional adalah untuk meningkatkan mutu pendidikan pada setiap jenis dan jenjang pendidikan. Pemerintah dalam hal ini Mentri Pendidikan Nasional sebagaimana yang 
tersusun dalam undang-undang Sistem Pendidikan Nasional No. 20 tahun 2003, secara eksplisit menyatakan:

"keberhasilan pendidikan dipengaruhi oleh banyak faktor, di antaranya adalah: faktor lingkungan guru, proses pembelajaran, materi, kurikulum dan lain-lain. Kurikulum adalah seperangkat rencana dan pengaturan mengenahi isi dan bahan pelajaran serta cara yang digunakan sebagai pedoman penyelenggaraan belajar mengajar (UU Sistem Pendidikan Nasional No. 20 tahun 2003)".

Kurikulum Tingkat Satuan Pendidikan sebagai kurikulum yang ditawarkan diharapkan akan memberikan kompetensi sesuai dengan tingkat pendidikan yang akan dicapai. Menurut Permendiknas No 22 tahun 2006 tentang Standar Isi, prinsip pelaksanaan kurikulum di setiap satuan pendidikan menegakkan lima pilar belajar, yaitu: (1) Belajar untuk beriman dan bertakwa kepada Tuhan Yang Maha Esa; (2) Belajar untuk memahami dan menghayati; (3) Belajar untuk mampu melaksanakan dan berbuat secara efektif; (4) Bealajar untuk hidup bersama dan berguna bagiorang lain; dan (5) Belajar untuk membangun dan menemukan jati diri melalui proses pembelajaran yang aktif, kreatif, efektif, dan menyenangkan.

Dalam proses pembelajaran guru sebagai pengajar dan siswa sebagai subjek belajar, diharapkan terdapat hubungan timbal balik dalam hal pengetahuan, kemampuan, sikap, agar proses belajar mengajar dapat berlangsung dengan efektif dan efisien. Para ilmuan diharapkan agar mengembangkan berbagai pengetahuan, misalnya metode, media, strategi dalam mengajar dan ilmu-ilmu lain yang dapat menunjang proses pembelajaran tersebut.

Menurut Khoir (2012) IPS adalah salah satu mata pelajaran di tingkat sekolah dasar pada hakikatnya merupakan suatu integrasi utuh dari disiplin ilmu-ilmu sosial dan disiplin ilmu lain yang relevan sebagai tujuan pendidikan. Mata pelajaran IPS berperan untuk mengfungsionalkan dan merealisasikan ilmu-ilmu yang bersifat teoritik ke dalam dunia kehidupan nyata di masyarakat, dengan kata lain bahwa IPS secara general, mencakup upaya untuk mengembangkan kemampuan pengetahuan, keterampilan, nilai, dan sikap siswa secara utuh.

Upaya meningkatkan hasil belajar IPS, diharapkan siswa memiliki kemampuan berfikir kritis, kreatif, dan inovatif yang sangat baik bagi pengembangan diri, intelektual, dan sosialnya. Dalam mewujudkan hal tersebut, maka diperlukan pembaharuan dalam pembelajaran IPS. IPS merupakan bagian dari ilmu sosial, keberadaan IPS dalam struktur program pembelajaran di SD sangat penting untuk diajarkan karena IPS memberikan pengetahuan, pembentukan nilai dan sikap serta keterampilan kepada siswa secara langsung berinteraksi dengan lingkungan yang ada di sekitarnya.

Selama ini pembelajaran IPS di SD Negeri 1 Subagan yang dilaksanakan cenderung ke arah pembahasan teori yang bersifat khusus (tematik teoritik) dan berdasarkan materi yang ada di dalam buku (text book oriented) sehingga terkesan bahwa bidang ini terdiri dari materi hafalan saja. Siswa SD Negeri 1 Subagan mengalami kesulitan untuk mencerna dan tidak dapat mengembangkan interaksi dengan sesamanya sebagai latihan hidup di masyarakat. Di sekolah siswa hanya memperoleh hafalan dengan tingkat pemahaman yang rendah. Siswa hanya tahu bahwa tugasnya adalah mengenal fakta, sementara pemahaman dan mengembangkan interaksi belum dapat mereka kuasai. Untuk itu pemerintah banyak melakukan usaha perbaikan melalui kurikulum yang lebih memberdayakan anak. Dalam kurikulum tersebut guru diharapkan untuk dapat memilih metode, strategi atau pendekatan pembelajaran yang tepat agar tujuan pembelajaran dapat tercapai (Nurhadi 2004: 2).

Pembelajaran IPS yang dilaksanakan di SD Negeri 1 Subagan yaitu menggunakan metode pembelajaran secara konvensional. Sementara siswa kelas 3 SD Negeri 1 Subagan diharuskan untuk menerima dan menghafal seluruh materi, sehingga hasil belajar yang diperoleh kurang memuaskan. Berdasarkan data hasil tes awal di kelas III SD Negeri 1 Subagan , menunjukkan data hasil belajar IPS masih tergolong rendah, yang ditandai dengan banyaknya siswa yang 
belum mencapai KKM yang telah ditetapkan yaitu 65. Dari hasil pembelajaran IPS terdapat 8 siswa $(25,53 \%)$ dari 34 siswa yang mencapai KKM, sedangkan 26 siswa $(76,47 \%)$ belum mencapai KKM dengan nilai rata-rata yang diperoleh 60,82.

Guna mengatasi permasalahan tersebut maka peneliti akan mencoba menggunakan metode yang dapat diterima dan mudah dipahami siswa kelas III SD Negeri 1 Subagan . Metode yang digunakan oleh peneliti ialah metode peta konsep yang menarik bagi siswa dengan memberikan beberapa warna pada bagan peta konsep, kreatif dalam mendesain bagan peta konsep, dan inovatif dalam mengembangkan pemikiran serta imajinasi pada siswa itu sendiri, guna meningkatkan hasil belajar siswa pada pembelajaran IPS. Dengan karakteristik anak SD kelas III yang berimajinasi tinggi serta berfikir kreatif, maka metode peta konsep ini dirancang semenarik mungkin bagi siswa sehingga dapat mengembangkan kekreatifitasannya dan imajinasinya. Metode peta konsep dapat juga membantu guru dalam mengembangkan materi pelajaran melalui bagan konsep, sehingga siswa lebih tertarik dalam belajar. Melalui bagan konsep siswa juga dapat lebih cepat dalam memahami materi yang disajikan oleh guru.

Berdasarkan urain di atas, peneliti tertarik untuk mengadakan penelitian dengan judul "Upaya Meningkatkan Hasil Belajar IPS Menggunakan Metode Peta Konsep Bagi Siswa Kelas III SD Negeri 1 Subagan Tahun Pelajaran 2017/2018”.

\section{METODE PENELITIAN}

Penelitian ini merupakan jenis Penelitian Tindakan Kelas. Di mana peneliti berkerjasama dengan kepala sekolah atau guru kelas. Tujuan utama Penelitian Tindakan Kelas adalah untuk meningkatkan praktek-praktek pembelajaran di kelas khususnya pada kelas III SD Negeri 1 Subagan . Jenis penelitian tindakan kelas yang digunakan dalam penelitian ini adalah kolaboratif, yaitu bahwa orang yang akan melakukan tindakan juga harus terlibat dalam proses penelitian ini. Tindakan dalam penelitian ini berupa penerapan metode peta konsep dengan tujuan untuk meningkatkan hasil belajar IPS siswa kelas III. Dalam kegiatan ini semua yang tergabung dalam penelitian ini terlibat secara penuh dalam proses perencanaan, tindakan, observasi, dan refleksi.

\section{Perencanaan}

Sebelum perencanaan dilakukan, perlu dilakukan observasi pada kelas III SDN 1 Subagan. Ditemukan beberapa kondisi yang mempengaruhi hasil belajar siswa masih rendah. Kenyataannya yang terjadi pada siswa yang selalu pasif dalam pembelajaran berlangsung, siswa mengalami kejenuhan saat menerima pelajaran, sehingga hasil belajar siswa masih rendah. Hal ini dapat dilihat pada perolehan nilai pada pembelajaran IPS di semester gasal yaitu lebih dari sebagian besar siswa mendapatkan nilai di bawah KKM.

Dari kendala yang mengakibatkan hasil belajar siswa masih rendah, maka persiapan perencanaan pembelajaran yang dilakukan adalah:

a. Mengidentifikasi kebutuhan siswa

b. Mengidentifikasi masalah yang dihadapi guru dan siswa saat pembelajaran.

c. Merumuskan indikator yang akan dicapai.

d. Merancang pembelajaran dengan menggunakan metode peta konsep

e. Menyiapkan alat dan bahan yang diperlukan.

f. Membuat lembar observasi siswa dan guru untuk melihat kondisi pembelajaran saat tindakan berlangsung.

g. Membuat lembar kerja evaluasi untuk melihat hasil yang telah dilakukan.

\section{Tindakan}

Penelitian ini dilaksanakan dalam 2 siklus. Siklus 1 terdiri dari 2 kali pertemuan dan siklus 2 terdiri dari 2 kali pertemuan. Tindakan siklus 1 dan siklus 2 dilaksanakan sesuai perencanaan yang tersusun dalam RPP. 


\section{Observasi}

Observasi merupakan pengamatan dengan tujuan tertentu. Observasi dilakukan secara langsung pada saat pelaksanaan siklus pembelajaran di kelas dengan tujuan mengumpulkan data secara kualitatif mengenai aktivitas guru dan siswa bertujuan untuk mencatat masalah yang terjadi pada saat pelaksanaan siklus pembelajaran yang kemudian akan menjadi refleksi sebagai tindak lanjut.

\section{Refleksi}

Kegiatan refleksi merupakan kegiatan peninjauan kembali terhadap kegiatan pembelajaran yang telah berlangsung. Refleksi ini dilakukan oleh observer terhadap praktikan dengan melihat segala aktivitas pembelajaran yang telah diamatinya. Dengan refleksi, segala kegiatan yang telah baik hendaknya dipertahankan dan kegiatan yang masih mengalami kekurangan dapat diperbaiki oleh praktikan supaya dalam pembelajaran berikutnya semua kekurangan-kekurangannya tersebut tidak terulang kembali.

Tabel 02 : Kisi-kisi lembar observasi partisipasi guru

\begin{tabular}{|l|l|}
\hline \multicolumn{1}{|c|}{ Komponen yang dinilai } & \multicolumn{1}{|c|}{ Sub komponen yang dinilai } \\
\hline $\begin{array}{l}\text { Aktivitas partisipasi guru } \\
\text { menggunakan metode } \\
\text { peta konsep dalam } \\
\text { pembelajaran }\end{array}$ & $\begin{array}{l}\text { 1. Mengidentifikasi ide pokok atau } \\
\text { prinsip yang melingkupi sejumlah } \\
\text { konsep }\end{array}$ \\
\cline { 2 - 2 } & $\begin{array}{l}\text { 2. Mengidentifikasi ide-ide atau konsep- } \\
\text { konsep sekunder yang menunjang ide } \\
\text { utama }\end{array}$ \\
\cline { 2 - 2 } & $\begin{array}{l}\text { 3. Menempatkan ide utama di tengah } \\
\text { atau di puncak peta tersebut }\end{array}$ \\
\cline { 2 - 2 } & $\begin{array}{l}\text { 4. Mengelompokan ide-ide sekunder di } \\
\text { sekeliling ide utama yang secara visual } \\
\text { menunjukan hubungan ide-ide tersebut } \\
\text { dengan ide utama }\end{array}$ \\
\hline
\end{tabular}

Tabel 03 : Kisi-kisi lembar observasi partisipasi siswa

\begin{tabular}{|l|l|}
\hline \multicolumn{1}{|c|}{ Komponen yang dinilai } & \multicolumn{1}{|c|}{ Sub komponen yang dinilai } \\
\hline $\begin{array}{l}\text { Aktivitas partisipasi } \\
\text { siswa saat pembelajaran } \\
\text { dengan menggunakan } \\
\text { metode peta konsep }\end{array}$ & $\begin{array}{l}\text { 1. Siswa membaca dan mencari ide } \\
\text { pokok pada setiap alinea yang mereka } \\
\text { baca }\end{array}$ \\
\cline { 2 - 3 } & $\begin{array}{l}\text { 2. Siswa mencari konsep umum pada } \\
\text { setiap materi }\end{array}$ \\
\cline { 2 - 2 } & $\begin{array}{l}\text { 3. Siswa mencari sub ide pokok dari ide } \\
\text { sentral yang mereka khususkan }\end{array}$ \\
\cline { 2 - 2 } & $\begin{array}{l}\text { 4. Siswa menempatkan ide pokok di } \\
\text { tengah atau di puncak peta konsep }\end{array}$ \\
\cline { 2 - 2 } & $\begin{array}{l}\text { 5. Siswa menempatkan sub ide pokok di } \\
\text { bawah ide sentral }\end{array}$ \\
\hline
\end{tabular}


Indikator keberhasilan penelitian ini ditandai dengan adanya peningkatan hasil belajar siswa secara klasikal lebih dari atau sama dengan $75 \%$ dari seluruh siswa tuntas belajar, dengan KKM 65 setelah melaksanakan pembelajaran dengan menggunakan metode peta konsep sesuai KKM mata pelajaran IPS di SD Negeri 1 Subagan .

\section{HASIL DAN PEMBAHASAN}

\section{Hasil}

Penelitian Tindakan Kelas ini dilaksanakan dalam 2 siklus. Hasil penelitian pada tiap-tiap siklus dideskripsikan sebagai berikut.

\section{Siklus I}
a. Perencanaan (Planning)
b. Tindakan (Action)
c. Pengamatan (Observing)
d. Refleksi (Reflecting)

Tabel 10 : Analisis Ketuntasan Hasil Belajar Siklus I

\begin{tabular}{|c|c|c|c|c|}
\hline No & Nilai & Siswa & Persentase & Kategori \\
\hline 1. & $\mathrm{X}<65$ & 20 & $58,52 \%$ & Belum Tuntas \\
\hline 2. & $\mathrm{X} \geq 65$ & 14 & $41,13 \%$ & Tuntas \\
\hline
\end{tabular}

Dari uraian di atas dapat diketahui bahwa pada siklus I siswa yang sudah memiliki ketuntasan hasil belajar 20 siswa atau 58,52\%. Hasil tersebut sudah mengalami peningkatan dibandingkan dengan hasil pra siklus yaitu 8 siswa atau 25,52\%. Akan tetapi hasil tersebut belum mencapai indikator keberhasilan penelitian yaitu $75 \%$ siswa tuntas belajar, sehingga perlu adanya tindakan lanjut pada siklus II

\section{Siklus II}

a.Perencanaan (Planning)

b.Tindakan (Action)

c.Pengamatan (Observing)

d.Refleksi (Reflecting)

Tabel 15. Persentase perbandingan julmah siswa tuntas hasil belajar pada Siklus I dan II

\begin{tabular}{|c|c|c|c|}
\hline \multirow{2}{*}{ Siklus } & \multicolumn{3}{|c|}{ Jumlah Siswa } \\
\cline { 2 - 4 } & Belum tuntas & Tuntas & $\begin{array}{c}\text { Persentase } \\
\text { Ketuntasan }\end{array}$ \\
\hline I & 14 & 7 & $58,82 \%$ \\
\hline II & 3 & 20 & $91,17 \%$ \\
\hline \multicolumn{2}{|c|}{ Peningkatan $(\%)$} & 31 & $32,35 \%$ \\
\hline
\end{tabular}

Dapat diketahui bahwa pada siklus II siswa yang sudah memiliki ketuntasan hasil belajar 31 siswa atau $91,17 \%$. Hasil tersebut sudah mengalami peningkatan dibandingkan dengan hasil siklus I. Berdasarkan indikator keberhasilan maka hasil siklus II dapat dikatakan bahwa 
perbaikan hasil belajar siswa melalui pembelajaran peta konsep dikatakan berhasil dengan berhasil 91,17\% siswa telah tuntas dalam penguasaan materi.

\section{Pembahasan}

Data yang diperoleh sebelum dan setelah dilaksanakan tindakan menunjukkan adanya peningkatan hasil belajar siswa yang ditunjukkan dengan hasil tes yang diperoleh. Sebelum diterapkannya metode peta konsep pada pembelajaran Ilmu Pengetahuan Sosial, diperoleh sebanyak 8 siswa atau 25,53\% tuntas dan 26 siswa atau 76,47\% belum tuntas. Namun setelah pembelajaran dengan menggunakan metode peta konsep dalam pembelajaran Ilmu Pengetahuan Sosial pada siklus I dan II diperoleh data bahwa hasil belajar siswa meningkat. Hasil tes siklus I diperoleh sebanyak 20 siswa atau 58,52\% tuntas dan 14 siswa atau 41,13\% belum tuntas. Berdasarkan data tersebut dapat dikatakan terjadi peningkatan ketuntasan hasil belajar siswa sebesar 32,99\% pada siklus I. Kemudian pada hasil tes siklus II menunjukkan 31 siswa atau 91,17\% tuntas dan 3 siswa atau 8,83\% belum tuntas.

Berdasarkan hasil tersebut dapat dikatakan terjadi peningkatan ketuntasan hasil belajar siswa sebesar $65,64 \%$ dibandingkan dari pra siklus dan sebesar 32,35\% dibandingkan pada siklus I. Berdasarkan data tersebut dapat diketahui bahwa terjadi peningkatan persentase jumlah siswa yang memiliki ketuntasan hasil belajar minimal pada siklus I, dan siklus II. Dengan adanya peningkatan yang terjadi pada siswa yang telah mencapai $91,17 \%$ siswa telah tuntas dan melebihi 75\% indikator keberhasilan maka dinyatakan bahwa perbaikan pembelajaran ini telah berhasil.

Selain dapat meningkatkan hasil belajar siswa, pembelajaran Ilmu Pengetahuan Sosial dengan metode peta konsep ini juga dapat meningkatkan motivasi belajar dan peningkatan partisipasi serta keaktifan belajar siswa yang berlangsung di dalam kelas selama pembelajaran berlangsung. Pada saat observasi awal yang dilakukan peneliti pada pembelajaran Ilmu Pengetahuan Sosial pada siswa kelas III SD Negeri 1 Subagan , pada saat proses pembelajaran berlangsung, guru menyampaikan materi pembelajaran yang hanya lebih mengarahkan terhadap pengalaman siswa saat berangkat sekolah dan tidak memberikan padangan yang lebih luas sehingga pola pikir siswa akan semakin berkembang dengan mengamati kondisi lingkungan sekitar kehidupannya. Pada siklus I dan II diterapkan pembelajaran Ilmu Pengetahuan Sosial dengan metode peta konsep pada siswa kelas III SD Negeri 1 Subagan . Masalah-masalah dan fenomena yang timbul dan berkembang di masyarakat kini mampu menjadikan sumber belajar siswa sehingga siswa mampu termotivasi untuk belajar dan lebih leluasa siswa berfikir. Sesuai dengan pendapat Darsono (2000: 4) belajar yaitu aktifitas mental atau psikis yang berlangsung dalam interaksi aktif dengan lingkungan yang maknanya adalah pengalaman. Hal ini menunjukan bahwa belajar memerlukan proses yang baik dan aktif agar siswa memiliki pengalaman dan mengambil ulang pengalaman yang pernah mereka peroleh.

\section{KESIMPULAN}

Dari hasil pembahasan yang telah disampaikan pada bab sebelumnya maka kesimpulan yang dapat diambil adalah Penggunaan Metode Peta Konsep Dalam Upaya Meningkatkan Hasil Belajar IPS Bagi Siswa Kelas III SD Negeri 1 Subagan Tahun Pelajaran 2017/2018 mengalami peningkatan, Hal tersebut dapat dilihat dari hasil belajar pada siklus I dan II diperoleh data bahwa hasil belajar siswa meningkat. Hasil tes siklus I diperoleh sebanyak 20 siswa atau 58,52\% tuntas dan 14 siswa atau 41,13\% belum tuntas. Kemudian pada hasil tes siklus II menunjukkan 31 siswa atau $91,17 \%$ tuntas dan 3 siswa atau 8,83\% belum tuntas. Dengan adanya peningkatan yang terjadi pada siswa yang telah mencapai $91,17 \%$ siswa telah tuntas dan melebihi $75 \%$ indikator keberhasilan maka dinyatakan bahwa perbaikan pembelajaran ini telah berhasil. 


\section{DAFTAR PUSTAKA}

Anni, C.Tri. dkk. (2006). Psikologi Belajar. Semarang: UPT MKK UNNES.

Anas Sudijono. (2008). Pengantar Statistik Pendidikan. Jakarta: Raja Grafindo Persada

Arikunto, Suharsimi. (2006). Prosedur Penelitian Suatu Pendekatan Praktik. Jakarta: Rineka Cipta.

BSNP. (2006). Peraturan Menteri Pendidikan Nasional No. 22 Tahun 2006 tentang Standar Isi. Jakarta: Depdiknas

Dahar. (1988). Pengertian Konsep. http://dc351.4shared.com/doc rdh dvg/preview.html diunduh pada tanggal 10 Maret 2014.

Darsono, Max, dkk. (2000). Dasar-Dasar Evaluasi Pendidikan. Semarang: IKIP Press.

Daryanto. (2009). Penelitian Tindakan Kelas dan Penelitian Tindakan Sekolah Beserta ContohContohnya. Yogyakarta: Gava Media.

Depdiknas,Dirjen Manajemen Pendidikan Dasar dan Menengah Direktorat Pembinaan TK dan SD,(2007), Pedoman penyuunan KTSP SD. Jakarta : Badan Standar Nasional Pendidikan

Doran, dkk. Iskandar. (2004). Peta Konsep. Fe.um.ac.id/wpcontent/uploads/2010/03/NurFatimah-Edit.pdf diunduh pada tanggal 9 April 2014.

Gino, H.J. (1993). Belajar dan Pembelajaran I. Yogyakarta: Universitas Negeri Yogyakarata .

Gunawan, Rudy. (2011). Pendidikan IPS. Bandung: Alfabeta.

Hamzah B. (2008). Profesi Kependidikan:Problema, Solusi, dan Reformasi Pendidikan di Indonesia. Jakarta: Bumi Aksara.

Isjoni dan Mohd. Arif Ismail. (2008). Model-Model Pembelajaran Mutakhir Perpaduan Indonesia-Malaysia. Yogyakarta: Pustaka Pelajar.

Khoir, Mazidatul. (2012). Paradigma PendLidikan IPS di Indonesia. https://mazidatulkhoir.wordpress.com/category/sosial diunduh pada tanggal 25 Februari 2014.

Nana Sudjana. (1998). Dasar-Dasar Proses Belajar Mengajar. Bandung: PT. Remaja

Rosdakarya Nasution, S. (1982). Didaktik Azas-Azas Mengajar. Bandung: Jemmars.

Novak, Gowin (1984), Ilmu Sosial Pendidikan, htpp//www.id.shvoong.com. diunduh pada tanggal 24 Maret 2014.

Nur. (2001).Pengertian Konsep http://dc351.4shared.com/doc_rdhdvg/preview.html diunduh pada tanggal 25 Februari 2014.

Nurhadi. (2004). Kurikulum 2004. (Pertanyaan dan Jawaban). Jakarta: Grasindo

Rifa'I, Achmad. (2009). Psikologi Pendidikan. Jakarta: Bumi Aksara.

Oemar, Hamalik. (1983). Metode Belajar dan Kesulitan Belajar. Bandung: Tursita.

Sanjaya, Wina. (2010). Strategi Pembelajaran Berorientasi Standar Proses Pendidikan. Jakarta: Kencana.

Slameto. (2003). Belajar dan Faktor-Faktor yang Mempengaruhinya. Jakarta : Rineka Cipta.

Sudjana, dkk. (2002). Metode Statistika. Bandung: Tarsito

Sugandi, Ahmad. (2006). Teori Pembelajaran. Semarang: UPT MKK UNNES.

Tony. (2005). Buku Pintar Mind Map. Jakarta: PT Gramedia Pustaka Utama

Undang-Undang RI No. 20 Tahun 2003 tentang SISDIKNAS. 2003Sahlberg, P. (2012). The most wanted: Teachers and teacher education in Finland. In L. Darling-Hammond \& A. Lieberman (Eds.), Teacher education around the world: changing policies and practices. London: Routledge. 